\title{
Editorial: IZA Journal of Migration
}

Amelie F Constant, Denis Fougère, Corrado Giulietti and Klaus F Zimmermann

*izajom@iza.org

Editors of the IZA Journal of Migration
Dear Reader,

We are delighted to introduce to you the IZA Journal of Migration (IZAJOM), the first online journal entirely dedicated to the economics of migration. Nowadays the migration phenomenon has reached critical complexity; hence, we believe that it is time to provide an outlet devoted to promote publication excellence and to foster the public debate in the field of migration economics.

The mission of IZAJOM is to become a landmark for all scholars who would like to publish innovative research on topics such as the determinants and consequences of human mobility, the assimilation of migrants and their children, migrants' occupational choices and remittance behavior, and the role of social networks. Furthermore, we would like to encourage submissions on the economic analysis of ethnicity, ethnic identity, and language.

With the research published in the IZAJOM, we hope to deepen the understanding about the economics of migration and to produce and share knowledge with the global community of scholars working in this field. To achieve such ambitious targets, we count on the support of world-class experts in the economics of migration that we have successfully brought together to serve as associate editors of the Journal.

The editorial team of IZAJOM will pursue prompt decision making and publication process. To ensure a fast procedure and achieve high quality publication, only articles which require minor revisions will be accepted for publication.

IZAJOM is accessible through the SpringerOpen Access system, which means free permanent electronic access immediately upon publication. We think that open access is a resourceful and innovative channel to disseminate widely and rapidly latest research.

We are grateful to Springer, the members of the Editorial Board and current as well as future authors and referees. Highly enthusiastic over this new venture, we will endeavor to render IZAJOM the leading publication outlet in the field.

\section{Amelie F. Constant \\ Denis Fougère \\ Editors \\ Corrado Giulietti \\ Managing Editor}

Klaus F. Zimmermann

Editor-in-chief for the Journal Series

(c) 2012 Constant et al.; licensee Springer. This is an Open Access article distributed under the terms of the Creative Commons Attribution License (http://creativecommons.org/licenses/by/2.0), which permits unrestricted use, distribution, and reproduction in any medium, provided the original work is properly cited. 

journal and benefit from:

- Convenient online submission

- Rigorous peer review

- Immediate publication on acceptance

- Open access: articles freely available online

- High visibility within the field

- Retaining the copyright to your article 